\title{
The Lower Nubian Egyptian Fortresses in the Middle Kingdom: A Strategic Point of View
}

\author{
By Eduardo Ferreira*
}

\begin{abstract}
The Ancient Egypt was a highly militarized society that operated within various theaters of war. From the Middle Kingdom period to the following times, warfare was always present in the foreign and internal policy of the pharaohs and their officers. One of these was to build a network of defensive structures along the river Nile, in the regions of the Second Cataract and in Batn el-Hagar, in Lower Nubia. The forts were relevant in both the defense and offensive affairs of the Egyptian army. Built in Lower Nubia by the pharaohs of the XII dynasty of the Middle Kingdom, these fortresses providing support to the armies that usually came from the North in campaign and allowed the ancient Egyptians to control the frontier with Kush. In fact, one of the most important features of these fortresses was the possibility to control specific territorial points of larger region which, due to it's characteristics, was difficult to contain. Although they were built in a period of about thirty-two years, these strongholds throughout the reign of Senuseret I until the rulership of Senuseret III, they demonstrate a considerable diversification in terms of size, defenses, functions, and the context operated. They were the main reason why Egypt could maintain a territory so vast as the Lower Nubia. In fact, this circumstance is verified in the Second Intermediate Period when all the forts were occupied by Kerma, a chiefdom that araised in Upper Nubia during the end of the Middle Kingdom, especially after c. 1720 BC, at a time when Egypt had bigger problems in the North (Delta) due to the Hyksos presence. Besides this fact, the lesser might of the central power in Egypt is also one reason why this society had lost control over these structures and, as a consequence, over Lower Nubia.
\end{abstract}

\section{The Long Beginnings of an Occupation}

Since the Old Kingdom period the Egyptian monarchy looked upon Nubia as a profitable source of materials from where came various resources: the ebony, the ivory, the incense, the ostrich feathers, the skins, some slaves, gold, copper and precious stones ${ }^{1}$. Everything began in the Old Kingdom's phase of exploration, passing through what some researchers call the "Egyptian imperialism" $^{2}$ of the Middle Kingdom, until the colonialism of the New

*Researcher - PhD Candidate, University of Lisbon, Portugal.

1. H. Hafsaas-Tsakos, "Between Kush and Egypt: The C-Group people of Lower Nubia during the Middle Kingdom and Second Intermediate Period," in Between Cataracts. Proceedings of the 11th International Conference of Nubian Studies (Warsaw, 2010), 390. In a short example from Harkhuf's biography: "[...] incense, ebony, $h k n w$-oil [...], phanter skins, elephant's tusks, and throwing-sticks [...]", it is possible to identify some of the goods that came from Nubia to Egypt; cf. B. J. Kemp, "Old Kingdom, Middle Kingdom and Second Intermediate Period c. 2686-1552 BC," in Ancient Egypt. A Social History, ed. B. G. Trigger, B. J. Kemp, D. O'Connor and A. B. Lloyd (Cambridge, 1983), 123.

2. S. T. Smith, Askut in Nubia: The Economics and Ideology of Egyptian Imperialism in the Second Millennium BC (London, 1995): 78-90. See also W. Y. Adams, "The First Colonial Empire: Egypt in Nubia, 3200-1200 BC," in Comparative Studies in Society and History, 26, 1, 
Kingdom. In these phases the Egyptian administrators, officials and employees choose to carry out different ways of occupying or controlling Wawat (Lower Nubia). For example, the edification of the fortresses in Lower Nubia was one these ways ${ }^{3}$.

There aren't many sources, either written or iconographic about the subjects of this paper. In fact, it is the archeological excavations made in the sites - were these fortresses used to lay - that give us more information regarding, not only the typology of these structures but also their roles in the strategic occupation of the region ${ }^{4}$. What could be the functions of these strong fortifications in Wawat? And what was their strategic importance in the region? Throughout this essay, we will try to provide a new light into these questions. Nevertheless, even with a complete absence of iconographic representations of these forts, we have textual sources from Semna West called "The Semna Dispatches", dated from the end of the Middle Kingdom ${ }^{5}$, in which we can find relevant data about the way these buildings helped the monarchy maintain Lower Nubia region.

Before our essay regarding the several ways of territorial control carried out in Lower Nubia during the Middle Kingdom, it is important to briefly observe the contexts before this period. During the Old Kingdom, the Egyptians gained a special interest in the resources that Wawat could provide. During the zenith of this period, the Group A populations ${ }^{6}$ in Wawat suffered from constant arrestment (either through military actions and economic coercion) by Egypt, who sought to weaken these same communities. At least three military campaigns are known, mainly punitive in nature, performed in

(January, 1984): 165-166. Zibelius-Chen argues that we can't use "imperialism" in the same terms as for the empires of the XIX century AD. An ancient society wouldn't have the capacity to dominate completely a region. In this case it would be Wawat; cf. S. T. Smith, "State and Empire in the Middle and New Kingdoms," in Anthropology and Egyptology. A Developing Dialogue, ed. J. Lustig (Sheffield, 1997), 66-67.

3. L. Török, Between Two Worlds. The Frontier Region between Ancient Nubia and Egypt 3700 BC-500 AD (Boston, 2009), 85-87.

4. C. Vogel, "Master Architects of Ancient Nubia: Space-saving solutions in the Middle Kingdom Fortresses," in Between Cataracts. Proceedings of the 11th International Conference of Nubian Studies (Warsaw, 2010), 421-430. See also G. A. Reisner, "Ancient Egyptian Forts at Semna and Uronarti," in Bulletin of the Museum of Fine Arts, 27(1929): 64-75. See also S. T. Smith, "Administration at the Egyptian Middle Kingdom Frontier: Sealings from Uronarti and Askut," in Aegean Seals, Sealings and Administration", ed. T. G. Palaima (Liége, 1990), 212 218. See also B. Trigger, Nubia. Under the Pharaohs (London, 1976), 71. See also A. Badawy, "Festunganlage," in Lexikon der Ägyptologie II, ed. W. Heck and W. Westendorf (Wiesbaden, 1977), 198. See also D. Randall-Maciver and L. Woolley, Buhen, 1 (Philadelphia, 1911), 119 120. See also Török, Between Two Worlds, 85-86.

5. P. C. Smither, "The Semna Dispatches," in Journal of Egyptian Archaeology, 31 (1945): 70-73. For a more in-depth analysis on these texts, see B. Kraemer and K. Liszka, "Evidence for Administration of the Nubian Fortresses in the Late Middle Kingdom: The Semna Dispatches", in Journal of Egyptian History (2016): 1-65.

6. Group A is a Neolithic culture that flourished in Lower Nubia around the fourth millennium BC and is divided chronologically in three phases: The Initial, Classic and Terminal; cf. W. Y. Adams, Nubia. Corridor to Africa (Princeton, 1977), 119. See also Trigger, Nubia. Under the Pharaohs, 35. See also L. Ross, Nubia and Egypt. 10000 B.C. to 400 A.D. From Prehistory to the Meroitic Period (Lewiston, 2013), 61. 
Lower Nubia. The first during Djer reign ( d dynasty $^{7}$ ) is described on an inscription found in Jebel Sheikh Suleiman ${ }^{8}$. The other two narratives of military enterprises against Group A belong to Kha-sekhem (II Dynasty) and Seneferu (IV Dynasty) ${ }^{9}$. Egypt's superiority over these Neolithic communities and the successive punitive campaigns from which the region suffered heavily weakened the populations, something led to the rise of an obscure period in terms of archaeological and historical knowledge. George Reisner refers it as Group $B^{10}$. The mentioned Seneferu's campaign ${ }^{11}$ was the last known Egyptian military campaign in Nubia. After this, there was a long gap interrupted only in the VI dynasty. It was also during this dynasty that the governor of Elephantine acquired the title of "Guardian of the South Gate"12. In some Old Kingdom textual sources (from the third dynasty) there are references related to the supervision of fortified structures, such as the "commander of the stronghold of Snt", the "commander of the stronghold Hsn in the Harpoon Nome", the "commander of the Cow stronghold", the "commander of the Desert Keeps and Royal Fortresses" and the "commander of the Ways of Horus"13.

Despite these military operations, in the Old Kingdom the relations between Egypt and Nubia (Group $\mathrm{C}^{14}$ ) were mainly peaceful, and essentially commercial, which can be traced back to the Predynastic period. Although Egypt during the Old Kingdom never territorially controlled Lower Nubia, it is necessary to mention some exceptions, where we can observe Egyptian

7. During the I dynasty, archaeological escavations made in Elephantina discovered a walled structure that must had the function of protecting the frontier in the region; cf. B. Williams, "New Light on the Relations between Early Egypt and Sudan," in Cahiers Caribéens d'Egyptologie, 1, (Fort de France, 2000), 7.

8. On an inscription in part pictographic, part hieroglyphic, it is possible to see on the right a tribal chief kneeling before an Egyptian boat, as well as individuals deceased in the river. In the left side, a figure appears to be arrested. According to William Adams, this scene represents the conquest of two settlements in an unknown region; cf. Adams, Nubia. Corridor to Africa, 138-139.

9. In a Seneferu's campaign that is described in the "Palette of Palermo", is reported that Egyptian army defeated the Nubians forces, bringing to Egypt a war spoils with 7.000 prisoners and 200000 of cattle; cf. Adams, Nubia. Corridor to Africa, 138-139.

10. For more information see also Id., 132-135. For Barry Kemp there is no material evidence in the period between the end of Group A and the beginning of Group C, that indicate a specific culture that required a new cultural horizon. This researcher supports this theory by saying that the campaigns and persecutions made on Group A by the Egyptians led the remaining Wawat's populations to choose a nomadic way of life between the Nile valley and the oases/wells adjacent to the desert; cf. Kemp, "Old Kingdom, Middle Kingdom and Second Intermediate Period", 124. See also D. O’Connor, Ancient Nubia. Egypt's Rival in Africa (Philadelphia, 1993), 13-23.

11. The mentioned cattle are a considerably exaggerated number, since so many heads would be extremely difficult to transport.

12. Adams, "The First Colonial Empire," 19.

13. J. H. Breasted, Ancient Records of Egypt, I. The First through the Seventeenth Dynasties (Chicago, 2001), 77-78.

14. During the Old Kingdom, the Egyptian sphere of influence, both commercial and political, extended only until the Second Cataract; cf. Adams, "The First Colonial Empire", 42. During the IV Dynasty, in the reigns of Khufu and Khefren the Egyptians explored the commercial careers of Toshka in Gebel el-Asr; cf. F. Monnier, Les Forteresses Égyptiennes. Du Prédynastique au Nouvel Empire (Bruxelles, 2010), 19. 
presence. These sites were Buhen, Ikkur, Kuban and Aniba, all fortified settlements of the IV and V dynasties, already with clear characteristics of forts ${ }^{15}$, which later in the Middle Empire will be confirmed. All of them were allocated in areas of extreme economic and commercial importance. For example, Kuban ${ }^{16}$ was in an important region of diorite extraction and Buhen was related to the extraction and work of copper ${ }^{17}$. Given the importance of the materials that were stored in these two settlements, we can assume the presence of an armed contingent that would probably patrol and oversee the population as well as the surroundings. Beyond that, these population centers should be able to provide some support to the military and commercial expeditions.

\section{A Strategic Point of View: The Middle Kingdom Egyptian Fortresses in Wawat}

The civil war that ended the Old Kingdom, which is called the First Intermediate Period, could have been one reason which allowed the thriving of the communities of Group $\mathrm{C}^{18}$. As noted earlier, Egypt's interest in its southern neighbors was almost exclusively commercial, something that changed with the Two Lands reunification during the rulership of Mentuhotep II. This pharaoh created the bases for a new military and commercial paradigm that would be used by the XII dynasty pharaohs (c. 1980-1765 BC ${ }^{19}$ ).

What motivated these changes? Why the Egyptians didn't keep the Old Kingdom policies? Certainly, the prosperity which the native populations of Lower Nubia and Upper Nubia reached, especially regarding military matters ${ }^{20}$, may have been one of the reasons the led the Middle Kingdom pharaohs to invest more intensely in military campaign in $\mathrm{Nubia}^{21}$ and later in the fortresses, built from the Second Cataract until the end of Batn el-Hagar, which because of their size must have had some restraint effect over the Nubian impetus. Naturally, we cannot ignore the existence of newer needs (social and economic) in the Egyptian society, especially in the higher classes, that could

15. W. Hamblin, Warfare in the Ancient near East to 1600 BC. Holy Warriors at the Dawn of History (London, 2006), 361.

16. Although the material evidence, is still not confirmed for Kuban has an Old Kingdom occupation; cf. B. J. Kemp, Ancient Egypt. Anatomy of a Civilization (London, 1989), 168.

17. Monnier, Les Forteresses Égyptiennes, 139.

18. Smith, Askut in Nubia, 78-79. See also Id., "State and Empire in the Middle and New Kingdoms", 66-68. See also Adams, Nubia. Corridor to Africa, 191-192. According to David O'Connor, the Group C society and Kerma society share some similarities, but in the most part is very different, especially in the artifacts and mortuary structures and rituals; cf. O'Connor, Ancient Nubia, 27.

19. L. M. Araújo, Os Grandes Faraós do Antigo Egipto (Lisbon, 2011), 103.

20. Trigger, Nubia. Under the Pharaohs, 85. See also Adams, "The First Colonial Empire," 46.

21. Hamblin, Warfare in Ancient Near East, 361. See also D. O’Connor, "Ancient Egypt and Black Africa - Early Contacts", in Expedition, 14 (1971), 6. 
originate the necessity regarding more goods (ex. gold, copper, diorite, carnelian and others ${ }^{22}$ ) and better and intensive ways to acquire them ${ }^{23}$.

The Middle Kingdom "imperialism" 24 consisted of a military occupation that exerted enormous pressure on the Group C populations, preventing them from revolting and disrupting Egyptian rule ${ }^{25}$. Beyond the military dimension, this imposition was also made by a commercial ${ }^{26}$ and social perspective. Thus, strategic control over Lower Nubia was done through frontier fees, as well as the day-to-day supervision of the native communities ${ }^{27}$.

The Egyptians built fifteen fortifications along the banks of the Nile in Lower Nubia $^{28}$ (see Figure 1) that guaranteed, each in its own way, the pharaonic intentions for the region. Strategically built in precise locations and with diverse military and civilian advantages, from north to south we have the fortifications of Ikkur (82x110m), Kuban (70x125m), Aniba (87x138m), Faras (75x85m) and Serra East (80xunknown), Buhen (215x460m), Khor (250x600m) Mirgissa (190x295m), Askut (77x87m), Shalfak (47x95m), Uronarti (57x114x126m), Semna West (135x135m), Kumma (70x117m) and Semna South (unknown) ${ }^{29}$. Most of these structures were built in the reign of Senuseret $\mathrm{I}^{30}$ (c. 1962-1928 BC ${ }^{31}$ ), while the fortresses of the Second Cataract and Batn el-Hagar were built in the reign of Senuseret III (c.1878-1842 BC ${ }^{32}$ ) except for Buhen (Senuseret I) and Mirgissa (Senuseret II who reigned between c. $1895-1878 \mathrm{BC})^{33}$. Beside the chronological difference, geography also

22. Kemp, "Old Kingdom, Middle Kingdom and Second Intermediate Period," 22-123. See also Ross, Nubia and Egypt, 136-138.

23. B. Muhs, The Ancient Egyptian Economy 3000-30 BCE (Cambridge, 2016), 76. See also Ross, Nubia and Egypt, 123-124. See also B. Manley, The Penguin Historical Atlas of Ancient Egypt (London, 1996), 50.

24. In the Egyptology community, there are several theories about the "Egyptian imperialism". Bruce Trigger argues saying that the twelfth dynasty was formed under an expansionist tradition that led later to imperialism; while John Wilson makes a distinction between the conjuncture of Middle Kingdom and the New Kingdom; William Adams tell us about a process based on an armed commercial monopoly and maintained by constant military campaigns, but especially by the fortresses built in the region of the Second Cataract; cf. Adams, Nubia. Corridor to Africa, 191-192. See also Smith, Askut in Nubia, 78-79. According to Roxanna Flammini, the period of expansion in the South by the Egyptian army has two phases. Firstly, there are the campaigns made in the beginning of the XII dynasty and secondly the phase of settling and fortify the region; cf. R. Flammini, "Ancient core-periphery interactions: Lower Nubia during Middle Kingdom Egypt (ca. 2050-1640 BC)," in Journal of World-Systems Research, 14, no 1 (2008): 54.

25. Adams, Nubia. Corridor to Africa, 165.

26. E. Yvanez, Rock Inscriptions from Semna and Kumma (Khartoum, 2010 ): 7.

27. K. Liszka, "We have come from the well of Ibhet: Ethnogenesis of the Medjay," in Journal of Egyptian History, 4 (2011): 156. See also Trigger, Nubia. Under the Pharaohs, 74. See also I. Shaw, Egyptian Warfare and Weapons (Buckinghamshire, 1991), 18. See also G. Callender, "The Middle Kingdom Renaissance," in The Oxford History of Ancient Egypt, ed. I. Shaw (Oxford, 2000), 155.

28. J. Baines and J. Málek, Atlas of Ancient Egypt (Oxford, 1980), 186.

29. D. Arnold, The Encyclopedia of Ancient Egyptian Architecture (London, 2003), 92.

30 Adams, Nubia. Corridor to Africa, 181.

31 M. J. Seguro, "Senuseret," in Dicionário do Antigo Egipto, dir. L. M. Araújo (Lisbon, 2001), 776. Except for Faras and Serra East which were made in the reign of Senuseret III.

32. Id., 777.

33. Ibid. C. Vogel, The Fortifications of Ancient Egypt 3000-1780 BC (Oxford, 2010), 11. 
played an important part in which these fortifications were built with very distinct characteristics, especially when compared to the area of Batn el-Hagar.

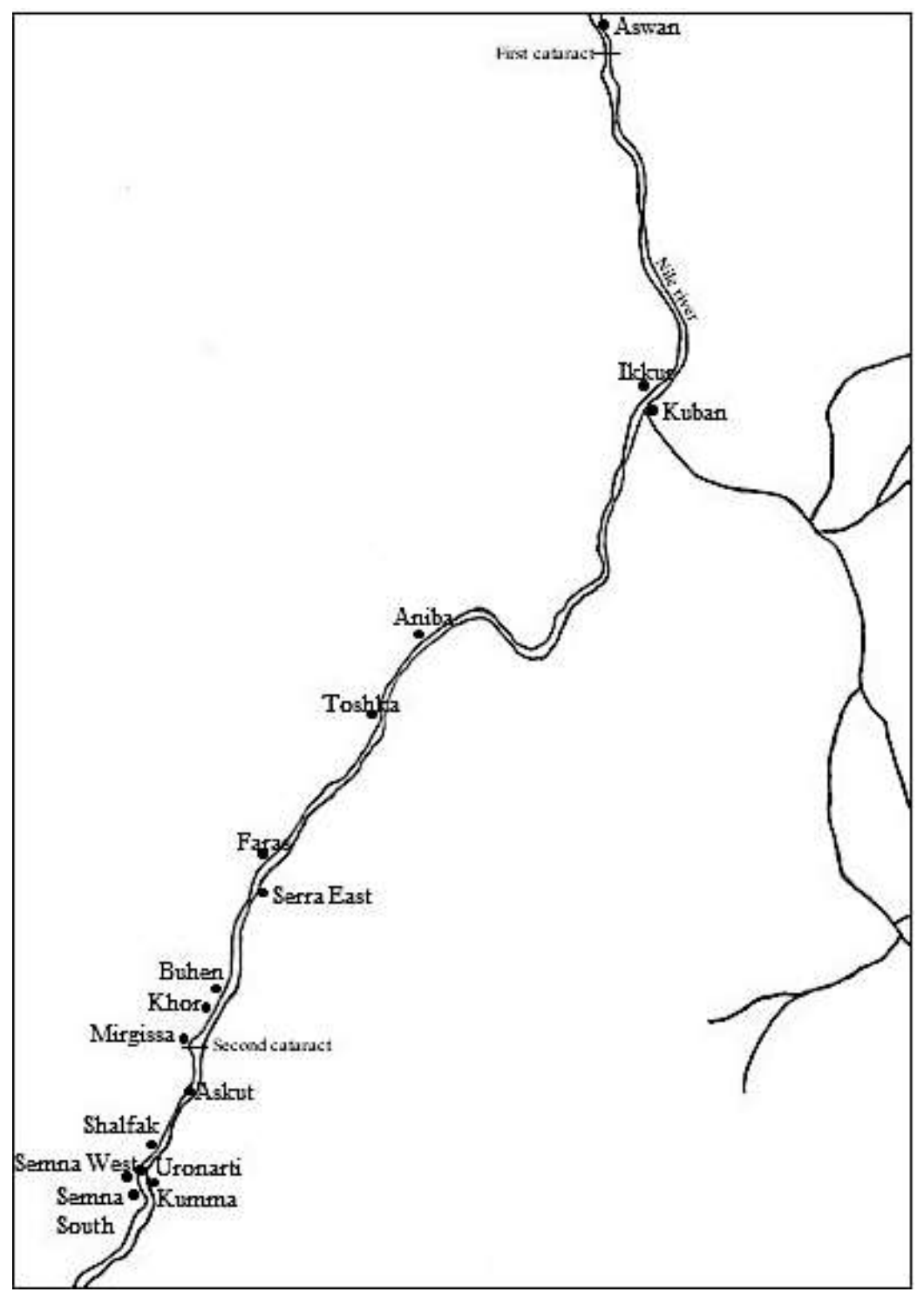

Figure 1. Map of Egyptian Middle Kingdom Fortresses in Lower Nubia

As a defensive structure, the main function of a stronghold is the protection and control of a certain territory, which then can differ in size and importance ${ }^{34}$. This is a reality present in many historiographic contexts, from the first walls of Jericho to the rattled fortresses of the eighteenth and nineteenth centuries of our time. Naturally, the Middle Kingdom Egypt was not an exception and built all these defensive structures in Lower Nubia to control a hostile and extremely difficult to contain territory ${ }^{35}$. These strongholds were built for four reasons ${ }^{36}$ :

34. E. Ferreira, Fortificar o Nilo. A ocupação militar egípcia da Núbia na XII dinastia (Lisbon, 2016): 73.

35. Id., 76. 
1. To secure the military control over Lower and Upper Nubia.

2. To control the commercial routes from $\mathrm{Kush}^{37}$.

3. To oversee the region for Kushite's raids and larger scale operations.

4. To support for pharaonic armies in campaign against Kush.

Most of the human circulation (civilian and military) used the Nile river as the main transportation route, and most of the border between the regions controlled by Egypt and Kush (Upper Nubia) was mostly composed by extremely hostile desert areas. But, despite this reality we can assume the presence of clandestine caravans, migrations and, above all, Nubian armed forces crossing the desert with the intention of looting, attacking populations and, ultimately, besieging fortresses ${ }^{38}$. Before analyzing each one of these aspects/reasons, which allowed the Egyptian dominion over the region, it is important to briefly note the geographical features that led the Egyptians to build these defensive structures in this region instead of another one.

For now, let us analyze only the fortifications built in the Second Cataract and in Batn el-Hagar. First, when we look to the Lower Nubia map and the places where these ten fortresses were built, the proximity between them is evident. It should be noted that from Buhen to Semna South, we only have 65 $\mathrm{km}$ of distance in a straight line $\mathrm{s}^{39}$. Why were so many structures built in such a short length? Firstly, it was the aid given when crossing the river in Batn elHagar, because when it loses caudal the river becomes impossible to sail ${ }^{40}$, and consequently, the passage needed to be made by land. Another explanation was the proximity of these fortifications to the frontier established with Kush that, of course, would require a greater capacity for protection and strategic control of the territory. Otherwise, a feature more intensified in the southerly forts that were the most concentrated ones (from Shalfak to Semna South). On the other hand, at north of Shalfak, between this fortress and Buhen, due to the greater distance regarding the border, we have almost half of the total distance, about $31 \mathrm{~km}^{41}$.

Another geographical difference that divides the fortresses placed in the Second Cataract to those built in Batn el-Hagar is the physiognomy of the terrain. The first mentioned region appears to be much more regular, something reflected in the architectural plans usually in a quadrangular (see Figure 2) or

36. Török, Between Two Worlds, 86-92. See also B. Williams, "Serra East and the mission of Middle Egyptian Fortresses in Nubia", in Gold of Praise: Studies on Ancient Egypt in Honor of Edward F. Wente (Chicago, 1999): 439-447. See also Shaw, Egyptian Warfare and Weapons, 18-19. See also Arnold, Ancient Egyptian Architecture, 91. See also Smith, Askut in Nubia, 80. See also Vogel, The Fortifications of Ancient Egypt, 12. See also Smith, "Administration at the Egyptian Middle Kingdom Frontier", 215-216.

37. O'Connor, Ancient Nubia, 37.

38. S. T. Smith, "To the Support of Heaven. Political and Ideological Conceptions of Frontiers in Ancient Egypt", in Untaming the Frontier, in Anthropology, Archaeology, and History (Arizona, 2005): 209. 133-134.

39. Vogel, The Fortifications of Ancient Egypt, 13. See also Ferreira, Fortificar o Nilo,

40. Trigger, Nubia. Under the Pharaohs, 68-69.

41. S. T. Smith, "Askut and the Role of the Second Cataracts Forts," in Journal of American Research Center in Egypt, 28(1991): 107-109. 
rectangular form (Buhen and Mirgissa). This factor allowed these fortresses to be much larger than those built in the south, which due to the greater irregularity of the terrain were considerably smaller ${ }^{42}$. In Batn el-Hagar the forts exhibit much more irregular morphologies; for example, Uronarti (see Figure 3) had a triangular shape ${ }^{43}$. In terms of defenses, these forts were very similar $^{44}$, had large adobe walls with rectangular towers, semicircular bastions, fortified doors, moats and ramps ${ }^{45}$.

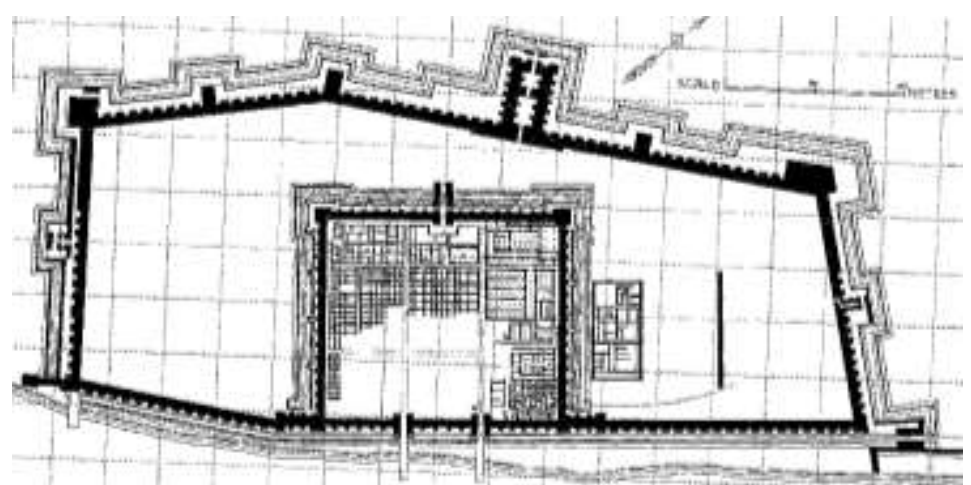

Figure 2. Buhen's Plan in the Middle Kingdom

Source: Monnier, Les Forteresses Égyptiennes, 138.

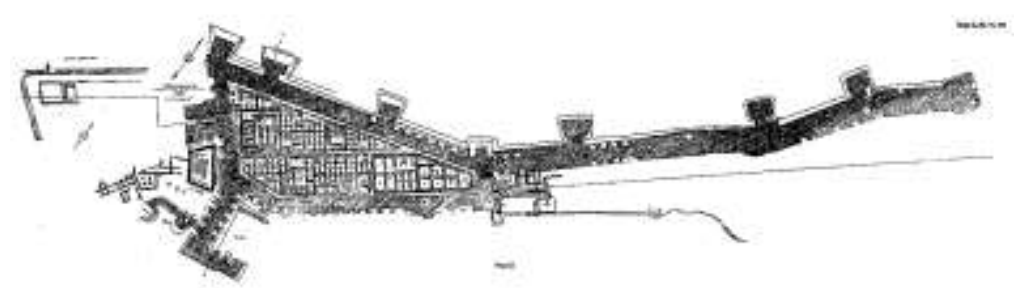

Figure 3. Uronarti's Plan in the Middle Kingdom Source: Monnier, Les Forteresses Égyptiennes, 152.

These fortresses had their own roles (despite not specific for only one) in the planning of the strategic control over the territory and each one of these structures played an important part for the same end ${ }^{46}$. Consider the case of Uronarti that would have an intense administrative office in the fortresses' network; in Mirgissa there would be a considerable arsenal; in Askut a large

42. Ferreira, Fortificar o Nilo, 131-132. See also Monnier, Les Forteresses Égyptiennes, 46. See also Hafsaas-Tsakos, "Between Kush and Egypt", 390. Besides the impossibility of sail in the river at a time of the year, the terrain's roughness in Batn el-Hagar helps to explain the greater concentration of forts, since they would have less capacity to develop internal structures for certain functions.

43. Kemp, "Old Kingdom, Middle Kingdom and Second Intermediate Period," 130-131.

44. Adams, Nubia. Corridor to Africa, 181. See also Vogel, The Fortifications of Ancient Egypt, 17-51.

45. Id., "Storming the Gates? Entrance Protection in the Military Architecture of Middle Kingdom Nubia", in Cities and Urbanism in Ancient Egypt, ed. M. Bietak, E. Czerny and I. Forstner-Müller (Wein, 2010), 301-302. See also Monnier, 2010, 46.

46. Vogel, "Master Architects of Ancient Nubia", 421. 
storehouse $^{47}$, or in Semna West, based on the amount of barracks which appeared in archaeological excavations, would be important regarding the housing of the soldiers, both those who belonged to the garrisons and those who were part of a military enterprise ${ }^{48}$.

One of the most constant and effective aspects that would contribute for the control of the territory were the patrols ${ }^{49}$ which scouted the regions around each one of these fortresses as well the frontier with $\mathrm{Kush}^{50}$. In fact, the forts should have had their own base of operations ${ }^{51}$. In the next two examples, taken from a written source called "The Semna Dispatches", we can verify a couple of descriptions about the scouting process ${ }^{52}$ :

$[\ldots]$ the $[\ldots$ in] the fourth month of the second season, [day...] came to report [to...]. He said concerning [...], "I departed upon the [track...] explained (?) [...] the [...] brought him [...] the frontier patrol. Then I returned [..., so he said]. I sent word about them to the fortresses that lie north." [...]

80. P. BM 10752, rt. 2-3.

[...] It is a communication to the lord, 1.p.h., to the effect that the warrior of the city of Hieraconpolis, Senu's son Heru's son Renoker, and the warrior of the city of Tjebu, Rensi's son Senwosret's son Senwosret, came to report to me, your humble servant, in Year 3, fourth month of the second season, day 2, at breakfast time on business of the soldier, Khusobek's son Mentuhotep's son Khusobek [...], who is substituting for the marine of the Ruler's Crew in the troop of Meha (near Abu Simbel), saying, "the frontier patrol that set out to patrol the desert margin extending near (?) the fortress 'Repeller of the Medjay' in Year 3, third month of the second season, last day, has returned to report to me saying, 'we found the track of thirty-two men and three donkeys, that they had trod $[\ldots]$ ', [...] the frontier patrol [...] my places", so [he] said. [...] command to (?) the troop [...] on the desert margin. I, your humble servant, have written [about this to..., as one fortress send a communication to another] fortress. [...]

81. P. BM 10752, rt. 3-4.

Regarding what was said here, we realized the existence of groups of scouts that had routes, previously delimited, that took them from one fortification to another. Unfortunately, it is not possible to identify which

47. Some researchers call this structure a "fortified granary"; cf. Smith, "Askut and the Role of the Second Cataracts Forts", 117.

48. Trigger, Nubia. Under the Pharaohs, 71. See also Vogel, "Master Architects of Ancient Nubia", 421.

49. The known officials regarding the scouting process are very scarce, but it's possible to highlight one example that can be related to this activity: the "commander of leaders of packdogs" (this official can be found in the text SNM 34327); cf. Yvanez, Rock Inscriptions from Semna and Kumma, 17. See also Id., 31.

50. In the following text (SNM 34317) we can identify a scouting process: "I travelled downstream with the frontier patrol. There has been no deceased during the travel southwards and nobody has been sent to prison. I judged and killed those rebels so that the sovereign truly praised me."; cf. Yvanez, Rock Inscriptions from Semna and Kumma, 29.

51. Ferreira, Fortificar o Nilo, 78. See also Arnold, Ancient Egyptian Architecture, 91.

52. Smither, "The Semna Dispatches", 71-72. 
fortresses are hypothetically referred in this first example, since north of Semna West there are Uronarti, Shalfak, Askut, Mirgissa and Buhen (not including those north of the latter). The other example also from Semna West provided us information about an operation that took forty Nubians and two Egyptian officers in scouting activities ${ }^{53}$. While in the first excerpt the main function seems to have been the transmission of information between fortresses ${ }^{54}$, in the second case, the source is referring to a process of territorial control whose main function was to find evidence of enemy clandestine military/civilian infiltrations in Lower Nubia. In this case, and as we can see from the source, this group eventually found a "track" of 32 men and 3 donkeys, although it is unclear if these were caught and what were their intentions. It should also be noted that these routes must have had several watchtowers, which would, firstly, ensure the good condition of the patrol by, at least, providing them with accommodation $^{55}$. The permeability and instability of the Egyptian border with Kerma's leadership must have forced the patrolling process to take place with some frequency ${ }^{56}$ and at long distances, a reality that will have linked the process of patrolling with the watchtowers. What was the relationship between the two elements? Were these supply points? Dorms? Would the patrol serve to renew the garrison of the tower? According to Carola Vogel, each Egyptian watchtower had a garrison of eight soldiers ${ }^{57}$, which likely came from the original fortresses' garrisons. With this possibility, it is plausible to assume that the soldiers who served in a certain watchtower were initially present in the scouting group that previously had the objective of passing through that structure and replacing the garrison. Based on these assumptions we can imagine the following scenario: a scouting group came out of a fortress with a certain number of soldiers and when it reached a watchtower, to be supplied or the opposite way, eight scout men should be instructed to stay in the tower, yielding the already eight who were in the structure. Then the patrol continued its route repeating it in other towers that could be in its way. Unfortunately, we do not know for how long a garrison had to stay in a tower, nor whether all the patrol groups had this function. Would the former garrison soldiers continue with the patrol? Or would they return to the fortress? This is a question that must be left open, but this couple of situations may depend on the distance between the tower and the fortification, or whether the patrol group had to maintain the initial number of soldiers. It is necessary to reinforce the idea that this is only an assumption based on the known context of the fortifications and military personnel present in the Second Cataract and Batn el-Hagar, since there is no data that can give us information on how the watchtowers and the patrol groups would relate. Furthermore, this renewal of these units was essential for the watchtowers' maintenance since it was very important for the

53. Id., 70-73.

54. Ferreira, Fortificar o Nilo, 90-93.

55. Regarding the supplies, we can assume that the patrols received them from the watchtower, although we can imagine that could be these groups themselves that brought supplies to the watchtowers.

56. Ferreira, Fortificar o Nilo, 248.

57. Vogel, The Fortifications of Ancient Egypt, 21. 
transmission of information between fortresses and for the strategic control of the territory.

As the scouting process can prove, although the fortresses were eminently static structures, they were in some dimensions quite "mobile" and "versatile", since they would be the support for activities with these faculties. Thus, beside the patrols in an offensive perspective, we have to the study the support that the forts gave to the military campaigns that came up the river ${ }^{58}$. Bruce Williams very well points out: "Within the continuous historical record available as precedent to the early Middle Kingdom, fortresses had not only been important, they had often been essential to the outcome of a campaign ${ }^{59 "}$. Before we look more closely to this aspect, let us see the toponymy of these same structures that show a strong offensive and strategic support for the conquest of the enemy in the south: Shalfak was "To conquer the foreign countries ${ }^{60 "}$; Uronarti was "Repelling the Iuntiu ${ }^{61 "}$ and Semna South was "Conqueror of Nubia"62. It is evident that each one of these names has a relationship with the control and subjugation of the region; even in some cases we can observe the reference of some specific tribes, like the Iuntiu. In a strategic perspective, this support was made of several types, although, in general, only in logistical manners ${ }^{63}$ :

1. Supplies.

2. Accommodation.

3. Armament.

4. Planning and information.

5. Assistance in moving.

The provision of supplies is a somewhat problematic matter, for it is not clear that these same fortresses were self-sustaining and thus we do not know to what extent they could provide food for the marching army. If they could give supplies to the armies, surely a large part of these supplies would be given by Askut, a small fortress with a large capacity to store food and other elements related to the survival of military operations ${ }^{64}$. According to Barry Kemp, Askut would have a far superior capacity to store food as which would be required to maintain not only the garrison and civilian population of that fort,

58. The Nile was the main route of transport of the Egyptian contingents in military expeditions against Nubian territories, since it was the fastest and safest method; cf. Ferreira, Fortificar o Nilo, 102.

59. Williams, "Serra East and the mission of Middle Kingdom fortresses in Nubia", 445446.

60. Given the geographical position of these fortresses, here the "foreign countries" could only be Kerma.

61. The Iuntiu are a Nubian population close to the Medjay; cf. C. C. Correia, "Núbios", in Dicionário do Antigo Egipto, dir. L. M. Araújo (Lisboa, 2001), 631.

62. Vogel, The Fortifications of Ancient Egypt, 16. Other examples are: "Destroying the Nubians" (Askut), "King Khakaure is Powerful" (Semna West) and "Warding off the Bows" (Kumma); cf. Török, Between Two Worlds, 88.

63. Vogel, The Fortifications of Ancient Egypt, 39-55. See also Id., "Master Architects of Ancient Nubia", 421-430.

64. Id., 425. See also R. G. Morkot, "Supplies", in The A to Z of Ancient Egyptian Warfare (Plymouth, 2010), 226-277. 
but the other ones around it ${ }^{65}$. Therefore, it is likely that a portion of these supplies were to be provided to the soldiers on the campaign ${ }^{66}$. For both housing and weapons supplies, we must highlight two strategically positioned forts that had guaranteed the support regarding these logistical issues. These two defensive structures are Mirgissa and Semna West, since both had a considerable set of barracks and arsenals (for this case we must emphasize Mirgissa $^{67}$ ).

Concerning the support of a campaign's planning, due to the distance from Kushite border, Buhen and Mirgissa would certainly have functions of this kind $^{68}$, and in terms of the sharing intelligence to the marching army, we must also consider Semna West as an important fortress for this type of function. Due to the fortress's ability of providing accommodations for huge number of soldiers, there was also the possibility of sharing information concerning the initial plan in time to change it.

The aid given by the fortifications in the passage of Batn el-Hagar region when the flow of the Nile river was smaller and made navigation impossible, can also be applied to the Egyptian forces. Further north, for example, the construction of a canal called "Beautiful are the Ways of Khekure Living Forever" ${ }^{\prime 9}$ during the reign of Senuseret III in the First Cataract, was built to facilitate the transition of this first geographical accident ${ }^{70}$. Therefore, it is natural that, in the case of the Second Cataract, both Buhen and Mirgissa had an important role in this situation. Even near the latter, it was found a ramp that allowed the crossing of the difficult rapids of Kabuka ${ }^{71}$. See the following excerpt $^{72}$ :

[...] Year 8 under the majesty of the King of Upper and Lower Egypt: Khekure, living forever. His majesty commanded to make the canal anew, the name of this canal being: "Beautiful are the Ways of Khekure [Living] Forever", when his majesty proceeded up-river to overthrow Kush, the wretched. [...]

In the expression "to overthrow Kush, the wretched", we can observe the main reason for the construction of this canal, the pharaoh was focused on dominating/vanquishing the enemy to the south, in Upper Nubia, Kerma ${ }^{73}$. Lastly, we must emphasize one of the less known fortress of that context,

65. B. Mcdermott, Warfare in Ancient Egypt (Gloucestershire, 2004), 48.

66. For more information's see Smith, "Askut and the Role of the Second Cataracts Forts", 117. See also Ferreira, Fortificar o Nilo, 106-107.

67. Vogel, "Master Architects of Ancient Nubia", 421. In Mirgissa's arsenal a variety of weaponry was found; from shields, dart heads in stone and arrowheads in crescent shape; cf. Trigger, Nubia. Under the Pharaohs, 71.

68. Ferreira, Fortificar o Nilo, 103.

69. Breasted, Ancient Records of Egypt, 291.

70. Ferreira, Fortificar o Nilo, 101.

71. Trigger, Nubia. Under the Pharaohs, 71.

72. Breasted, Ancient Records of Egypt, 292.

73. Ferreira, Fortificar o Nilo, 102. Kerma appears under the name Kush for the first time in Egyptian sources in a prisoners list on the fortress of Buhen; cf. Török, Between Two Worlds, 87. 
Semna South, which was slightly south of Semna West. Is a small structure (for the parameters of the remaining fortresses) and we do not know for sure what was its function in the network, but it is likely that campaigns support was it's focus. Being the closest structure to the border with Kush must have made this fort the last support (for supplies or lodging) for the armies. Particularly regarding accommodation, in the possibility of a defeat and the army's retreat, Semna South could be the first point of support for this action ${ }^{74}$. Beside this element, it would not only provide protection to the soldiers, but also counterattack if the enemy tried to take the fort.

Outside the military manners, two other aspects must be analyzed. In the first place, it is important to mention one of the most obvious civilian dimensions that these forts had: the customs control that was carried out by these fortresses. See the following example ${ }^{75}$ :

[...] Southern boundary, made in the year 8, under the majesty of the King of Upper and Lower Egypt, Khakaura Senuseret III who is given life forever and ever; in order to prevent that any negro should cross it, by water or by land, with a ship, or any herds of negroes; except a negro who shall come to do trading in Iken [Mirgissa] or with a commission. Every good thing shall be done with them, but without allowing a ship of the negroes to pass by Heh [Semna?], going downstream, forever. [...]

It seems clear to us from this example that the fortifications built on the Second Cataract and at Batn el-Hagar had a very strong function of administrative $^{76}$ and commercial control of the vessels, essentially Kushite's, who were upstreaming the river towards Heh (probably the fortress of Semna West $)^{77}$. Structure based facts that "The Semna Dispatches" had given to us, should be particularly important in this respect ${ }^{78}$ :

[...] Nubians [arrived in Year] 3, fourth month of the secind season, day 7, at [evening] time in order to do some bartering. What [they] had brought was bartered [...] the bartering thereof. [...] Six other Nubians arrived at the fortress "Powerful is Khakaure, the deceased", in order to do some bartering according

74. Ferreira, Fortificar o Nilo, 105.

75 .Shaw, Egyptian Warfare and Weapons, 18.

76. W. B. Emery, H. S. Smith and A. Millard, The Fortress of Buhen. The Archaeological Report (London, 1979): 3.

77. Muhs, Ancient Egyptian Economy, 86. See also Shaw, Egyptian Warfare and Weapons, 18-19.

78. Smither, "The Semna Dispatches", 70-73. Recent studies made by Kraemer and Liszka in missing texts from the "Semna Dispatches" that Paul Smither didn't analyzed, show us a very similar description regarding a trade process between the Egyptians and the Nubians: "It is a communication to the master, 4 Nehesy-women arrived at [the fortress Khakaure is Powerful (Semna West)] in regnal year 3, month 4 of Peret, day [6 at the time of] morning. They said, "It is to do trade that we have come." So, they said. What they brought was traded. A payment for it [was given to them.] They went south [to the place] that they came from [on] day 7 at the time of [evening], after bread and beer were [given to] them according [to the rule]. It is a communication about it. The servant-there had the High [Steward] Senmeri who is in the fortress Warding off the Bows (Kumma) bring [it.] (Semna Dispatch 8, column 6); cf. Kraemer and Liszka, "The Evidence for Administration of the Nubian Fortresses", 15. 
to this [...] in the fourth month of the secon season, day 8 . What they had brought was bartered. They siled south on the same day to the place they had come from.

79. P. BM 10752, rt. 1.

[...] A response to this dispatch has been made in the dispatch sent to him about [...] Nubians who arrived at the fortress "Powerful is Khakaure, the deceased", in the fourth month of the second season, day 7, at evening time and who were sent back to the place they had come from in the fourth month of the second season, day 8, at time of morning.

83. P. BM 10752, rt. 5.

It appears that the Nubians from Upper Nubia needed a "license" to allow them to trade in the fortress and in territory under Egyptian control. Although, given the excerpt, these merchants, probably, could not transpose the fortress of Mirgissa (Iken) further north and this place would be the last moment when they would be able to trade. Certainly, there would be some kind of payment associated with this "license", and the existence of such documentation allowed the Egyptian administration and soldiers to better control who traded within the fortresses premises and what their background was ${ }^{79}$.

Lastly, the other extra military aspect in which the fortresses had an active role in the control of the region was in the imposition of tributes to the subjugated tribes, although for the Middle Kingdom it is difficult to know in what consisted these tributes. For example, Senuseret I had tried, through military campaigns, to impose heavy tributes to Kerma ${ }^{80}$. As we shall see later, the fortifications built north of Buhen had a more evident bearing on the control of the local populations and the tax systems that would have been applied by the Egyptians, since these fortresses were built in a region that had the largest population groups.

Unlike the relatively close to each other Second Cataract fortifications, the structures built north of Buhen, since they covered a much larger territory, we were not able to identify a network between them ${ }^{81}$. This, of course, should make communications much harder, something that would have forced the construction of several watchtowers and signal stations ${ }^{82}$ to ensure an efficient coordination between these fortresses and also allowing them to serve as outposts for the control of local populations. As previously mentioned, the forts of Ikkur, Kuban, Aniba, Faras and Serra East, from north to south respectively, were built in the areas within the highest demographic density of Group C (see Figure 4), which led William Adams to argue that these forts would have as their main function the administrative control of these communities. For example, Aniba was built alongside the Nile's fertile banks, where there was a

79. Ferreira, Fortificar o Nilo, 117-118.

80. Trigger, Nubia. Under the Pharaohs, 65-71. See also Ferreira, Fortificar o Nilo, 125126.

81. Adams, Nubia. Corridor to Africa, 181. At least in a way like the southern forts, naturally they were linked together, but the distances had made the communications much more difficult.

82. For more information's see Vogel, The Fortifications of Ancient Egypt, 20-21. 
strong presence of Group C populations. Nevertheless, this shouldn't be the only one function of the defensive structures because some of them were built close to very important strategic positions, like Kuban, which was located near Uadi el-Allaqi, and the meandered desert traffic control that lead to profitable mines and quarries ${ }^{83}$.

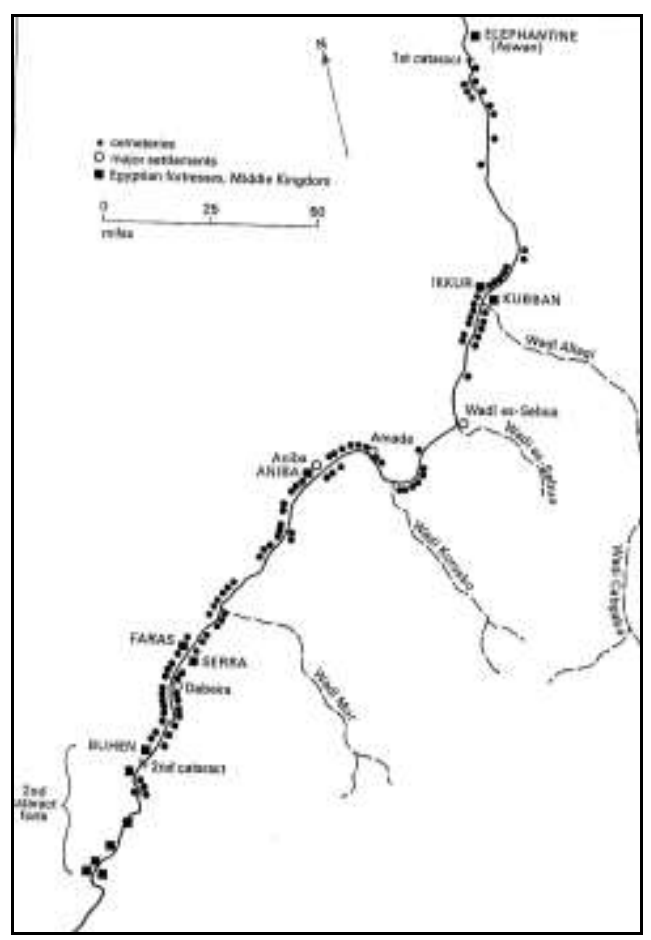

Figure 4. Group C settlements in Lower Nubia Source: Adams, Nubia. Corridor to Africa, 146.

Regarding our knowledge about the fortress of Ikkur, which was built on the west side of the Nile river, unfortunately, it is by, no means, abundant. It is known that Ikkur's evolution was contemporary with Kuban's and the fortress had a rectangular plan with thick walls, bastions, towers and a moat ${ }^{84}$. Probably, this one had functions very like those previously attributed to Kuban, particularly the strategic control over the local population. However, the absence of this fortification on the Onomasticon Ramesseum has led some researchers to believe that this structure would be a complement of Kuban ${ }^{85}$.

Eighty kilometers south of Kuban we find Aniba, built on the western bank of the Nile ${ }^{86}$. It was a walled structure of rectangular shape (phases I and II), protected by spores, very similar to those in Buhen and Mirgissa, especially their citadels ${ }^{87}$. Aniba was one of the first egyptian military occupations in Lower Nubia $^{88}$ and it was built in one of the most fertile areas of Wawat ${ }^{89}$,

83. Adams, Nubia. Corridor to Africa, 187-188.

84. Monnier, Les Forteresses Égyptiennes, 128.

85. Ibid.

86. Shaw, Egyptian Warfare and Weapons, 22-23. See also Vogel, The Fortifications of Ancient Egypt, 27.

87. Monnier, Les Forteresses Égyptiennes, 130.

88. Vogel, The Fortifications of Ancient Egypt, 27. 
which explains, mostly, the existence near this fortification of a considerable size Nubian settlement. Regarding this fact, it is relatively safe to say that Aniba would have, like most of the others, the function of controlling both the upper lands of the region and, of course, the high native demography that was settled in the area. It is also worth noting Aniba's isolation regarding structural support from other strongholds, much like what was happening further south in Askut (although here the distance was much greater). In fact, Aniba is an exception in most of all Egyptian fortresses, because all of them have at least one fort nearby. For example, Faras and Serra East were also very close to each other and the same happened with Kuban and Ikkur. This geographical feature shows us that, firstly, the need of watchtowers to ensure an effective communication between fortresses, and, secondly, Aniba would also be important in supporting military campaigns that went south, because it was a secure point in a vast region with no egyptian structures ${ }^{90}$. A reality attested also by this fort being the oldest military Egyptian occupation in Wawat.

The forts of Faras and Serra East ${ }^{91}$ would surely be related between themselves, being one a complement of the other. Faras was built on the western bank of the Nile and it was a small fort from the reign of Senuseret III and, although today it is considerably distant from the river, archaeological interventions showed that this fortress had a fluvial port, proving contact between Faras and the river waters ${ }^{92}$. Both Ikkur and Faras, smaller strongholds compared to their respective neighbors, were built on the west bank of the river, while, on the other hand, on the eastern shore the biggest forts were built. Why did the Egyptians use this pattern? The answer may lie in the position of the indigenous settlements and with the most important Uadis in Lower Nubia, which were all on the east bank of the Nile; many of these waterways were used as roads for transporting raw materials. Naturally, the Egyptians needed to have a bigger presence in the east bank of the river to better secure the profitable commercial traffic and maintain the peace with the local tribes.

Serra East, which the Egyptians had given the suggestive name of "Repelling the Medjai"93 was built in Senuseret III time ${ }^{94}$, on the east bank of the Nile and a close to the north of Buhen. It had a rectangular shaped structure with two floors, which would be filled by a huge number of shops and warehouses $^{95}$. Both Faras and Serra East have a somewhat ambiguous geographic position, and in fact it is hard to define a specific function for these fortifications ${ }^{96}$. Nevertheless, we can't ignore the Egyptian toponymy which

89. Ibid. See also Williams, "Serra East and the mission of Middle Kingdom fortresses in Nubia", 443.

90. At least structures with the capacity to provide help to these contingents. Of course, it is possible to assume the existence of other buildings near Aniba, but archaeology didn't found them yet.

91. Ian Shaw gives to Faras and Serra East a propagandistic function; cf. Shaw, Egyptian Warfare and Weapons, 23.

92. Monnier, Les Forteresses Égyptiennes, 132.

93. Not completely excavated; cf. Monnier, Les Forteresses Égyptiennes, 133.

94. Vogel, The Fortifications of Ancient Egypt, 11.

95. Monnier, Les Forteresses Égyptiennes, 132-133.

96. Adams, Nubia. Corridor to Africa, 187. 
clearly refers to it as a structure to control the indigenous populations, particularly the Medjai with a considerable concentration in the area. Regarding the control of farms and routes coming in from the desert to the Nile, their function should be residual ${ }^{97}$. During excavations in the Serra East, it was discovered a cistern about $25 \times 10 \mathrm{~m}^{98}$, something original and not found in any of the other Egyptian fortresses in Nubia. Why was there such an infrastructure? Mainly to supply the marching armies and the military and civil population of the forts and their neighbors. Where would the water come from? Certainly, the region's extremely low rainfall couldn't be the source of the water, so the possibilities for the origins of this vital resource could be either the presence of a source of drinkable water, a water table for example, or simply the river itself. In a more military manner, beside the probably support for military campaigns, some researchers argue that Serra East should have served also as a prison for dissidents ${ }^{99}$.

The human migrations and movements in general were a very important factor, regardless of the hostile desert conditions and the difficulties which some native groups would face when cross this type of zones. We found evidence of this reality and like in the other southern fortresses; the existence of scouts was essential to the survival of the Egyptian presence in the Wawat. Both the scouting parties and the Nubians would have to consider water points, wells or oases, because these would be essential for their survival; the following passage describes a patrol that had intercepted a group of hostiles, or at least clandestine Nubians ${ }^{100}$.

[...] It is a communication to you, 1.p.h., to the effect that the two warriors and seventy Medjay-people who had departed following that track in the fourth month of the second season, day 4, returned to report to me on the same day at evening time, bringing three Medjay-men, and four male and female infants (?), saying, "We found them on the south of the desert margin beneath the inscription of the summer season, and also three women (?)", so they said. I then questioned these Medjay-people, asking, "From where have you come?". They then replied, "It's from the well of the region of Ibhayet (southeast of the Second Cataract) that we have come". [...]

80. P. BM 10752, rt. 2-3.

In this excerpt, which belongs to "The Semna Dispatches", it is described that process of scouting in the area would be done in a more intensive way for the Group $\mathrm{C}$ most populated regions, where the movements would be much more frequent ${ }^{101}$. Firstly, here we can see the composition of a scouting party;

97. Ibid.

98. Monnier Les Forteresses Égyptiennes, 133.

99. Williams, "Serra East and the mission of Middle Kingdom fortresses in Nubia", 449.

100. Smither, "The Semna Dispatches", 71.

101. Southern attacks should more frequent and problematic because of the Kerma's power in Upper Nubia at south of Batn el-Hagar; cf. S. T. Smith, "Pharaohs, Feasts, and Foreigners, Cooking, Foodways, and Agency on Ancient Egypt's Southern Frontier", in The Archaeology and Politics of Food and Feasting in Early States and Empires, ed. T. L. Bray (New York, 2003): 43. See also Williams, "Serra East and the mission of Middle Kingdom fortresses in Nubia", 444-447. 
in this case they were only two Egyptian soldiers, probably high in rank and seventy Medjay men. It is quite curious to see the presence of so much more natives and probably the answer for this manner lies in the most probably low capacity in which Egypt could bring garrisons to the fortresses and, on the other hand, the higher knowledge of the geography and water points regarding these Nubians and, of course, locally they also should outnumber the Egyptian forces ${ }^{102}$. Naturally, this way of organizing scouts could bring problems to the Egyptian point of view because if the natives weren't in the Egyptian side it could pave the way for an eventual betrayal ${ }^{103}$.

Beyond the control that was made by the patrols, the Egyptians also forced the Nubian chiefs to pay tributes to the monarchy ${ }^{104}$. In the biography of Sarenput I, the governor of Aswan in Senuseret's I reign, had an allusion about the tribute's payments made by these populations, mainly called by the Egyptian authorities of Medjaiu ${ }^{105}$. In fact, the fortress of Kuban ${ }^{106}$ were built one kilometer south of the Dakka temple ${ }^{107}$, exactly in an important area of contact between the ethnic tribes of Medjay ${ }^{108}$. So, we can assume that the collection of tributes would certainly be among the functions within the regional context ${ }^{109}$, and it would serve as a support base for tax collectors, who were escorted by the sa-per, a security force whose purpose was to protect these officials ${ }^{110}$. The existence of this type of armed group suggests the danger associated with this function, which often would be contested by the local

102. There were some reasons why Egypt couldn't bring more soldiers to these structures, but mainly it was because the difficulty to incite the Egyptian soldiers to go far away from home in a dangerous land and were the supplies could be low. This reality could explain the greatness of some of these fortifications. In fact, these fortresses didn't need a garrison with a lot of warriors mainly because of their capacity of defense which were, probably, enough to sustain sieges from the local enemies; cf. Ferreira, Fortificar o Nilo, 235-238. For more information about these manners see J. Martínez Babón, Historia Militar de Egipto durante la Dinastía XVIII (Barcelona, 2003), 113. See also Trigger, Nubia. Under the Pharaohs, 71. See also Williams, "Serra East and the mission of Middle Kingdom fortresses in Nubia", 436. See also Arnold, Ancient Egyptian Architecture, 91. See also Kemp, Ancient Egypt. Anatomy of a Civilization, 177. See also Ferreira, Fortificar o Nilo, 227-229.

103. Id., 247-249.

104. Trigger, Nubia. Under the Pharaohs, 62-63.

105. Liszka, "Ethnogenesis of the Medjay", 156. Probably, these ethnicities were one with the most presence in Lower Nubia.

106. Kuban had a rectangular plan with a double wall (a main wall and a secondary element with semicircular bastions) and a moat. In Senuseret III reign the original wall was destroyed and rebuilt with a bigger wall, which exceed the within wall zone; cf. Monnier, Les Forteresses Égyptiennes, 129. Kuban was close to an important source of gold a copper; cf. Kemp, "Old Kingdom, Middle Kingdom and Second Intermediate Period", 122. Also, Kuban didn't have a direct access to the Nile, certainly there was a road to a small port, something that would be central for the supply of this fortification; cf. Monnier, Les Forteresses Égyptiennes, 129.

107. Ibid.

108. Kemp, "Old Kingdom, Middle Kingdom and Second Intermediate Period", 122.

109. According to Barry Kemp, Kuban had a function related to the acquisition of cattle. Were these animals a result of the tributary system? cf. Id., 135.

110. J. M. Parra, "Los policías del Antiguo Egipto: duros y corruptos", in Historia National Geographic, 128 (2014): 18-19. 
tribes, probably leading to skirmishes, since the payment of taxes would not be seen with pleasant eyes by the locals.

\section{Conclusions}

All the Middle Kingdom fortresses built in Lower Nubia suggest an extreme concern for the strategic control over this region, but also a consciousness of a weak border, for even if the Nile were effectively controlled, the other territories (mainly desert), due to its characteristics was quite permeable and difficult to oversee. A reality in which the scouts were the most important unit, since these military groups allow the Egypt's control over a wide territory. But, how often were these patrols made? It is difficult for us to answer with certainty to this question, but the attendance in which these patrols were made, should be subjected to the following elements: the size of the fortress's garrison; the distance that needed to be patrolled; the typology of populations within the region; the geographical location/routes and, in the end, the frequency of Kushite infiltrations. The combination of all these factors would dictate the regularity with which the patrols were made as well as their effectiveness. There would certainly be more scouts and more soldiers in these parties involved in zones with hostile populations under the Egyptian sphere of influence or in places where there would be pre-established desert transition routes (especially those that were closer to the border) that could be used by enemies.

The creation of this tight network (only in the Second Cataract and Batn elHagar) composed by the fortresses and watchtowers that fill the gaps created by the unavoidable distances between these forts, show us the thought given by the egyptian officials, architects and engineers regarding the strategic position of this buildings in Wawat. The existence of these communication lines allowed, when it was possible ${ }^{111}$, the dispatch (probably with smoke signals) of important intel regarding various aspects in little time, as for example, the approach of an hostil army.

These defensive structures were the reflection of an adaptation to a new reality that didn't exist in the previous periods, which led the Egyptians to choose different military approach and economic/social policies. Nevertheless, even if the military campaigns were the most intensive way of subjugating the populations, when we look to the highly controlled trade or the taxes and supervision that were imposed and made over the Nubian tribes, it is possible to oversee the role of these fortifications in this region (Lower Nubia). We can also verify that these forts controlled the most important sectors in which the Egyptian presence would be concerned. It is clear the importance of these fortifications in all affairs regarding the territorial maintenance of Wawat and the constant Kushite's military expeditions stagnation that sought to weaken the egyptian presence in the region.

111. Some scouts' descriptions suggest that sometimes, especially when the message was more complex, the need of movement of groups to transmit the information. Besides this, with bad weather conditions the signals could not be seen. 


\section{Bibliography}

Adams, W. Y. Nubia, Corridor to Africa. Princeton: Princeton University Press, 1977.

Adams, W. Y. "The First Colonial Empire: Egypt in Nubia, 3200-1200 BC". Comparative Studies in Society and History, 26,n. 1 (January 1984): 36-71.

Araújo, L. M. Os Grandes Faraós do Antigo Egipto. Lisbon: A Esfera dos Livros, 2011.

Arnold, D. The Encyclopedia of Ancient Egyptian Architecture. London: I. B. Tauris, 2003.

Badawy, A. "Festunganlage". Lexikon der Ägyptologie, II, edited by Wolfgang Helck and Wolfhart Westendorf, 194-203Wiesbaden: Otto Harrassowitz, 1977.

Baines, J., Málek, J. Atlas of Ancient Egypt. Oxford: Phaidon Press, 1980.

Breasted, J. H. Ancient Records of Egypt, I, The First through the Seventeenth Dynasties. Chicago: University of Chicago Press, 2001.

Callender, G."The Middle Kingdom Renaissance". The Oxford History of Ancient Egypt, edited by Ian Shaw, 137-171. Oxford: Oxford University Press, 2000.

Correia, C. C. "Núbios". Dicionário do Antigo Egipto, dir. L. M. Araújo, 631.. Lisbon: Editorial Caminho, 2001.

Emery, W. B., Smith, H. S. and Millard, A. The Fortress of Buhen. The Archaeological Report. London: Egypt Exploration Society, 1979.

Ferreira, E. Fortificar o Nilo. A ocupação militar egípcia da Núbia na XII dinastia. Lisbon: Chiado Editora, 2016.

Flammini, R. "Ancient core-periphery interactions: Lower Nubia during Middle Kingdom Egypt (ca 2050-1640 BC)". Journal of World-Systems Research, 14, n. 1 (2008): 50-74.

Hafsaas-Tsakos, H. "Between Kush and Egypt: The C-Group people of Lower Nubia during the Middle Kingdom and Second Intermediate Period". Between Cataracts, Proceedings of the $11^{\text {th }}$ International Conference for Nubian Studies, 389-396. Warsaw: Warsaw University, 2010.

Hamblin, W. J. Warfare in the Ancient near East to 1600 BC, Holy Warriors at the Dawn of History. London: Routledge, 2006.

Kemp, B. J. Ancient Egypt, Anatomy of a civilization. London: Routledge, 1989.

Kemp, B. J. "Old Kingdom, Middle Kingdom and Second Intermediate Period c. 26861552 BC". Ancient Egypt, A Social History, edited by B. G. Trigger, B. J. Kemp, D. O'Connor and A. B. Lloyd, 71-174.. Cambridge: Cambridge University Press, 1983.

Kraemer, B. and Liszka, K. "Evidence for Administration of the Nubian Fortresses in the Late Middle Kingdom: The Semna Dispatches". Journal of Egyptian History, 9(2016): 1-65.

Liszka, K. "We have come from the well of Ibhet: Ethnogenesis of the Medjay". Journal of Egyptian History, 4(2011): 149-171.

Manley, B. The Penguin Historical Atlas of Ancient Egypt. London: Penguin Books, 1996.

Martínez Babón, J. Historia Militar de Egipto durante la Dinastía XVIII. Barcelona: Museo Egipci de Barcelona, Fundació Arqueològica Clos, 2003.

Mcdermott, B. Warfare in Ancient Egypt. Gloucestershire: Sutton Publishing, 2004.

Monnier, F. Les Forteresses Égyptiennes. Du Prédynastique au Nouvel Empire. Bruxelles: Éditions Safran, 2010. 
Muhs, B. The Ancient Egyptian Economy 3000-30 BCE. Cambridge: Cambridge University Press, 2016.

Morkot, R. G. "Supplies". The A to Z of Ancient Egyptian Warfare, 226-227. Plymouth: Scarecrow Press, 2010.

O’Connor, D. "Ancient Egypt and Black Africa - Early contacts". Expedition, 14(1971): 2-7.

O'Connor, D. Ancient Nubia. Egypt's Rival in Africa. Philadelphia: the University Museum, 1993.

Parra, J. M. "Los policías del antiguo Egipto: duros y corruptos". Historia National Geographic, 128(2014): 18-21.

Randall-Maciver, D and Woolley, L. Buhen, 1. Philadelphia: University Museum, 1911.

Reisner, G. A. "Ancient Egyptian Forts at Semna and Uronarti". Bulletin of the Museum of Fine, 27(1929): 64-75.

Ross, L. Nubia and Egypt. 10,000 B.C. to 400 A.D. From Prehistory to the Meroitic Period. Lewiston: The Edwin Mellen Press, 2013.

Seguro, M. J. "Senuseret". Dicionário do Antigo Egipto, dir. L. M. Araújo. Lisbon: Editorial Caminho, 2001, 776-778.

Shaw, I. Egyptian Warfare and Weapons. Buckinghamshire: Shire Publications, 1991.

Smith, S. T. "Administration at the Egyptian Middle Kingdom frontier: Sealings from Uronarti and Askut". Aegean Seals, Sealings and Administration, ed. T. G. Palaima, 197-216. Liége: Université de Liége, 1990.

Smith, S. T. "Askut and the Role of the Second Cataract Forts". Journal of American Research Center in Egypt, 28(1991): 107-132.

Smith, S. T. Askut in Nubia: The Economics and Ideology of Egyptian Imperialism in the Second Millennium BC. London: Kegan Paul International, 1995.

Smith, S. T. "Pharaohs, Feasts, and Foreigners, Cooking, Foodways, and Agency on Ancient Egypt's Southern Frontier". The Archaeology and Politics of Food and Feasting in Early States and Empires, edited by T. L. Bray, 39-64. New York: Springer US, 2003.

Smith, S. T. "State and Empire in the Middle and New Kingdoms". Anthropology and Egyptology. A Developing Dialogue, edited by J. Lustig, 66-89. Sheffield: Sheffield Academic Press, 1997.

Smith, S. T. "To the Support of Heaven, Political and Ideological Conceptions of Frontiers in Ancient Egypt". Untaming the Frontier, in Anthropology, Archaeology, and History, 207-237. Arizona: The University of Arizona Press, 2005.

Smither, P. C. "The Semna Dispatches". Journal of Egyptian Archaeology, 4 (1945): 70-73.

Török, L. Between Two Worlds. The Frontier Region between Ancient Nubia and Egypt 3700 BC-500 AD. Boston: Brill, 2009.

Trigger, B. Nubia, Under the Pharaohs. London: Thames and Hudson, 1976.

Vogel, C. The fortifications of Ancient Egypt 3000-1780 BC. Oxford: Osprey Publishing, 2010.

Vogel, C. "Master Architects of Ancient Nubia: Space-saving solutions in the Middle Kingdom Fortresses". Between Cataracts, Proceedings of the $11^{\text {th }}$ International Conference for Nubian Studies, 421-430. Warsaw: Warsaw University, 2010.

Vogel, C. "Storming the Gates? Entrance Protection in the Military Architecture of Middle Kingdom Nubia". Cities and Urbanism in Ancient Egypt, eds. M. Bietak, E. Czerny and I. Forstner-Müller, 299-320. Wein: Österreichische Akademie der Wissenschaften, 2010.

Williams, B. "New Light on the Relations between Early Egypt and Sudan". Cahiers Caribéens d'Egyptologie, 1, 5-21. Fort de France: Société d'Anthropologie, 2000. 
Vol. 5, No. $1 \quad$ Ferreira: The Lower Nubian Egyptian Fortresses in the Middle...

Williams, B. "Serra East and the mission of Middle Kingdom fortresses in Nubia". Gold of Praise: Studies on Ancient Egypt in honor of Edward F. Wente, 435-453. Chicago: Oriental Institute, 1999.

Yvanez, E. Rock Inscriptions from Semna and Kumma. Khartoum, 2010. 